\title{
PEMBERDAYAAN BERBASIS ASET DESA : UPAYA PENCIPTAAN LAPANGAN KERJA BAGI MASYARAKAT DESA
}

\author{
(Studi Di Desa Mandalamekar dan Desa Cikadut, Kecamatan Cimenyan, Kabupaten Bandung,
} Propinsi Jawa Barat)

\author{
Khairul, Mulyati, Darrini \\ Universitas Widyatama \\ Program Studi Akuntansi \\ Cikutra, Bandung, Jawa Barat 40125, Indonesia \\ email : khairul.shaleh@widyatama.ac.id
}

\begin{abstract}
Abstrak
Penelitian ini memformulasikan sebuah model pengelolaan aset desa secara optimal yang berorientasi pada pembukaan peluang kerja bagi masyarakat pedesaan dan peningkatan pendapatan desa. Besarnya anggaran desa, idealnya memberikan dampak terhadap perekonomian masyarakat desa, namun bisa saja hal ini tidak terwujud karena beberapa faktor internal maupun eksternal pemerintah desa. Naiknya jumlah asset yang dikelola oleh pemerintah desa karena kenaikan anggaran belanja desa, memerlukan pengelolaan yang baik. "Baik" dalam arti memberikan dampak terhadap perekonomian masyarakat dan memberikan kontribusi pendapatan bagi pemerintah desa. Penelitian ini menggunakan pendekatan deskriptif kualitatif, yaitu suatu metode penelitian dengan tujuan memberikan gambaran objektif tentang realitas objektif yang terjadi di suatu kondisi atau lingkungan. Penelitian ini menggambarkan tentang pemanfaatan asset pemerintah desa berpotensi menciptakan lapangan kerja bagi masyarakat. Metode pengumulan data melalui observasi, wawancara mendalam, diskusi fokus, studi kepustakaan dan dokumentasi. Penelitian dilakukan pada dua desa yaitu desa Mandalamekar dan Desa Cikadut Kec. Cimenyan Propinsi Jawa Barat.
\end{abstract}

Kata Kunci : Pemerintah Desa, Aset Desa, Lapangan Kerja, Pemanfaatan Aset

\section{Abstract}

This research formulates an optimal model of village asset management that is oriented towards opening employment opportunities for rural communities and increasing village income. The size of the village budget, ideally, will have an impact on the economy of the village community, but this may not be realized due to several internal and external factors of the village government. The increase in the number of assets managed by the village government due to the increase in the village budget requires good management. "Good" in the sense of having an impact on the economy of the community and contributing income to the village government. This study uses a qualitative descriptive approach, namely a research method with the aim of providing an objective picture of objective reality that occurs in a condition or environment. This research illustrates the use of assets of the village government has the potential to create jobs for the community. Methods of data collection through observation, in-depth interviews, focus discussions, literature studies and documentation. The study was conducted in two villages, namely the villages of Mandalamekar and Desa Cikadut, Kec. Cimenyan, West Java Province.

Keywords: Village Government, Village Assets, Employment, Asset Utilization

\section{Pendahuluan}

Sejak undang-undang desa Nomor 06 tahun 2014 berlaku, desa memiliki wajah baru dimana desa melalui pemerintah desa dapat mengolah kekayaannya secara mandiri sesuai dengan kebutuhan masyarakatnya. kekayaan yang terdapat di desa dapat berupa fisik ( $h a r d$ ) maupun berupa non fisik (Soft). Irigasi pertanian, tanah kas desa (beberapa desa penyebutannya berbeda), jalan desa, Kantor desa, Balai pertemuan desa dan pasar desa merupakan beberapa contoh kekayaan desa dalam bentuk fisik. Sementara beberapa contoh kekayaan desa yang sifatnya nonfisik dapat berupa tradisi kesenian lokal, upacara keagamaan, kebudayaan lokal, atau dapat juga berupa cerita mitodologi yang 
hidup dalam tradisi masyarakat desa yang kemudian menjelma menjadi kearifan lokal masyarakat.

Kekayaan yang dimiliki oleh desa pengelolaannya diserahkan kepada pemerintah desa atau kepada entitas lokal yang telah mendapatkan pengakuan dan persetujuan dari masyarakat setempat. "kekayaan desa" dalam penyebutannya dapat juga diistilahkan sebagai aset desa. Kekayaan fisik setara dengan asset berwujud sementara kekayaan nonfisik setara dengan aset tak berwujud.

Aset desa sepatutnya digunakan untuk kepentingan masyarakat di pedesaan. Infrastruktur pertanian digunakan oleh petani untuk menunjang kegiatan pertanian, begitupun dengan akses jalan perkebunan rakyat digunakan untuk menunjang kegiatan perkebunan, serta beberapa jenis asset lainnya yang digunakan untuk kepentingan masyarakat. Asset yang dimiliki oleh pemerintah desa tujuan akhirnya dalam rangka meningkatkan kesejahteraan masyarakat desa.

Dana desa yang berasal dari pemerintah pusat merupakan sumber pendapatan baru bagi pemerintah desa [1], nilainya cukup besar dapat menambah kapasitas keuangan desa sehingga pemerintah desa dapat memaksimalkan pelayanan kepada masyarakat melalui pembangunan desa. Kecendrungan peningkatan dana desa sejak beberapa tahun terakhir mestinya diikuti dengan peningkatan jumlah aset yang dimiliki oleh desa. Nilai aset yang cukup besar pada skala desa diperlukan pengelolaan secara efisien dan efektif untuk kepentingan masyarakat.

Pengelolaan aset desa tidak hanya sekedar melakukan inventarisasi dengan tujuan agar dapat dilakukan pengamanan terhadap aset tetapi perlu optimalisasi penggunaan aset agar setiap aset yang dimiliki oleh pemerintah desa dapat memberikan manfaat ekonomis bagi pemerintah desa (Pendapatan Asli Desa) maupun bagi masyarakat dalam bentuk peningkatan daya beli. Walhasil dana desa yang di transfer dari pemerintah pusat dapat memberikan dampak ekonomi bagi masyarakat pedesaan di Indonesia.

Tentu untuk memanfaatkan aset desa secara optimal membutuhkan perangkat desa yang paham cara pemanfaatan aset yang dapat memberikan dampak ekonomi bagi masyarakat dan pemerintah desa. Kemampuan mengidentifikasi aset desa secara fungsional tidak dapat dioperasionalkan secara normal dan aset secara fungsional masih dapat digunakan namun biaya pemeliharaan yang cukup besar, jika tidak dimanfaatkan secara optimal akan menyerap anggaran pemeliharaan cukup besar. Hal ini merupakan kemampuan mendasar yang diperlukan bagi perangkat desa dalam pengelolaan aset desa secara optimal.

Selain itu, pemanfaatan aset desa dalam bentuk apapun tetap memprioritaskan kepentingan masyarakat desa setempat. Pemanfaatan aset desa oleh masyarakat diharapkan dapat dirasakan langsung manfaatnya dan berdampak pada peningkatan daya ekonomi masyarakat. Jika aset tidak dapat dimanfaatkan oleh masyarakat setempat disebabkan oleh pertimbangan kemampuan ekonomis masyarakat dan pemeliharaan yang cukup mahal, maka pemerintah desa dapat melakukan penawaran kerjasama dengan pihak lain yang berasal dari luar desa.

Lebih jauh lagi, pengelolaan aset desa saat ini didorong semangat pengelolaan dengan paradigma baru yaitu aset desa diharapkan tidak sekedar digunakan sebagai penunjang tugas pokok dan fungsi pemerintah desa, tetapi aset dapat juga dimanfaatkan sebagai upaya peningkatan pendapatan asli desa dan saat bersamaan menciptakan lapangan kerja bagi masyarakat pedesaan. Jika cara ini dapat dijalankan dengan baik oleh pemerintah desa, maka dapat memicu penurunan jumlah penggangguran yang ada di pedesaan.

Untuk dapat menjalankan paradigma baru pengelolaan asset desa dibutuhkan kapasitas perangkat desa yang tidak sekedar memahami pengelolaan aset secara teknis penatausahaan, lebih daripada itu mampu melakukan inovasi pengelolaan aset yang berorientasi pada optimalisasi penggunaan dan pemanfaatan aset desa, termasuk memiliki pengetahuan entrepreneur. Bekal kemampuan ini dibutuhkan ketika terdapat aset desa kondisi dan fungsi tidak maksimal digunakan sebagai penunjang tugas pokok dan fungsi (tupoksi). Perlu langkah-langkah optimalisasi pemanfaatan dengan cara menyewakan, kerjasama atau kemitraan. Pemerintah desa dapat memilih salah satu dari tiga metode pemanfaatan. Namun apapun metode yang dipilih, sebaiknya kemampuan entrepreneur perlu dimiliki perangkat desa, kemampuan melihat peluang atas potensi manfaat yang akan diperoleh oleh pihak ketiga, pihak pemerintah desa, dan terpenting demi kepentingan ekonomi masyarakat, ketika aset desa akan dimanfaatkan oleh pihak lain.

Berdasarkan pada penjelasan sebelumnya maka diperlukan pengelolaan aset desa, tidak hanya sekedar bersifat administratif tetapi lebih daripada itu diperlukan pengelolaan yang memberikan dampak pada masyarakat pedesaan dan sekaligus memberikan kontribusi pendapatan bagi pemerintah desa. Maka yang menjadi output dalam penelitian ini memformulasikan sebuah model pemberdayaan berbasis aset desa secara optimal dalam rangka pembukaan peluang kerja bagi masyarakat pedesaan.

\section{Tinjauan Pustaka}

Pemberdayaan masyarakat desa berbasis pada aset bukan merupakan wacara baru dalam upaya meningkatkan kemampuan ekonomi masyarakat. Suatu pendekatan untuk meningkatkan 
kesejahteraan sebuah komunitas, menurut Hadi [2] Dalam publikasi penemuan risetnya menggambarkan dua cara dalam menanggulangi kemiskinan. Pada pendekatan pertama, lebih menekankan pada kondisi komunitas yang serba kekurangan dengan beberapa permasalahan ekonomi sehingga memunculkan kesan "negatif" sementara pendekatan kedua lebih menekankan pada potensi yang sudah ada pada komunitas sehingga potensi yang ada menjadi sumber daya awal dalam melakukan pemberdayaan pada komunitas dalam konteks masyarakat desa.

Faktor pendampingan merupakan salah satu faktor yang menentukan keberhasilan usaha pemberdayaan [3], disamping beberapa faktor lainnnya. Diperlukan pendampingan secara intensif yang diperankan oleh lembaga formal ataupun informal melalui pemberian motivasi, hard skill, pengetahuan, membangun kerjasama kelompok untuk kepentingan bersama merupakan upaya yang dapat dilakukan untuk mewujudkan tujuan pemberdayaan. Demikian juga dengan pemberdayaan dengan menggunakan potensi aset desa yang sudah ada sebelumnya. Aset desa yang digunakan sebagai basis pemberdayaan masyarakat dapat menjadi motor penggerak yang memberikan dampak ekonomi bagi warga desa.

Berdasarkan pada Peraturan Pemerintah Nomor 71 Tahun 2010 tentang Standar Akuntansi Pemerintah [4] aset didefinisikan sebagai, "sumber daya ekonomi yang dikuasai dan/atau memiliki oleh pemerintah sebagai akibat dari peristiwa masa lalu dan dari mana manfaat ekonomi dan/atau sosial masa depan diharapkan dapat diperoleh, baik oleh pemerintah maupun masyaraka, serta dapat diukur dalam satuan uang, termasuk sumber daya nonkeuangan yang diperlukan untuk penyediaan jasa bagi masyarakat umum dan sumber -sumber daya yang dipelihara karena alasan sejarah dan budaya."

Sementara definisi aset menurut [5] Peraturan Menteri Dalam Negeri No. 01 Tahun 2016 seperti berikut:

"Aset Desa adalah barang milik Desa yang berasal dari kekayaan asli milik Desa, dibeli atau diperoleh atas beban Anggaran Pendapatan dan Belanja Desa (APB Desa) atau perolehan Hak lainnya yang sah. Perolehan hak lainya dapat berupa hibah yang diberikan dari pihak lain berupa aset yang digunakan oleh pemerintah desa dalam menunjang penyelenggaraan pemerintah desa"

Pengelolaan aset merupakan rangkaian kegiatan mulai dari perencanaan, pengadaan, penggunaan, pemanfaatan, pengamanan, pemeliharaan, penghapusan, pemindatanganan, penatausahaan, pelaporan, penilaian, pembinaan, pengawasan dan pengendalian aset Desa. Berikut lingkup kekayaan asli desa yang diatur dalam peraturan pengelolaan aset desa.
Tabel 1

Lingkup Kekayaan Asli Desa

\begin{tabular}{|c|l|}
\hline No & Kekayaan Asli Desa \\
\hline 1 & Tanah Kas Desa \\
2 & Pasar Desa \\
3 & Pasar Hewan \\
4 & Tambatan perahu \\
5 & Bangunan Desa \\
6 & Pelelangan ikan yang \\
& dikelolah oleh desa \\
7 & Pelelangan Hasil Pertanian \\
8 & Hutan Milik Desa \\
9 & Permandian Umum \\
10 & Lain-lain Kekayaan Asli Desa \\
\hline
\end{tabular}

Pemanfaatan Aset Desa adalah pendayagunaan aset Desa secara tidak langsung dipergunakan dalam rangka penyelenggaraan tugas pemerintahan desa dan tidak mengubah status kepemilikan. Skema pemanfaatan dapat digambarkan sebagai berikut :

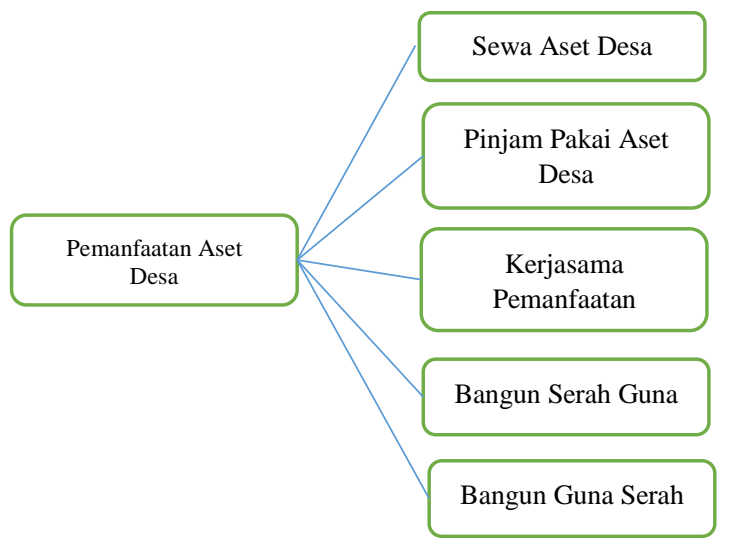

Gambar 1 Klasifikasi Pemanfaatan Aset Desa

Pengelolaan aset desa dalam lingkup pemerintah desa dikelola secara berjenjang yang dimulai dari kepala desa selaku Pemegang Kekuasaan Pengelolaan Asset Desa (PKPADes). Sekertaris Desa bertidak selaku Pembantu Pengelola Aset Desa (PPADes). Jenjang terakhir dari pengelolaan asset desa adalah Kepala Urusan Umum bertindak selaku pengurus aset desa. Struktur pengelolaan aset desa tergambar sesuai dengan bagan struktur dibawah ini.

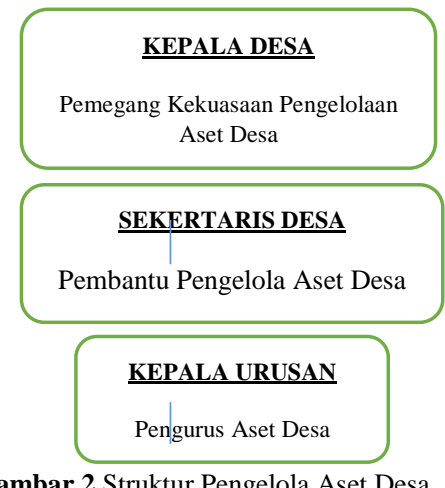

Gambar 2 Struktur Pengelola Aset Desa 


\section{Potensi Tenaga kerja dan Desa}

Sebaran jumlah penduduk lebih banyak berada di wilayah pedesaan dengan beragam kategori dan tingkatan umur yang bervariasi. Meskipun memiliki potensi tenaga kerja dengan jumlah besar namun kenyataanya sebagian besar dari jumlah tersebut belum terserap dalam lingkungan kerja. Sebagian besar tersebut tidak memiliki pekerjaan yang bersifat tetap. Beberapa terserap ke sektor pertanian untuk waktu-waktu tertentu. terutama saat musim tanam. Sementara beberapa lainnya sektor pekerjaan infrastuktur dengan imbalan upah kerja atau mendapatkan pekerjaan konstruksi atas permintaan perorangan. Kondisi pekerjaan seperti ini menyebabkan kontinuitas penghasilan yang diharapkan semakin tidak menentu, berharap dari pekerjaan yang bersifat musiman. Jika mengacu pada kriteria pengangguran terbuka sesuai dengan konseptual Badan Pusat Statistik diuraikan menjadi empat kriteria utama yaitu:

a. Mereka yang tak punya pekerjaan dan mencari pekerjaan

b. Mereka yang tidak punya pekerja dan mempersiapkan usaha

c. Mereka yang ta kpunya pekerjaan dan tidak mencari pekerjaan, karena merasa tidak mungkin mendapatkan pekerjaan

d. Mereka yang sudah punya pekerjaan, tetapi belum memulai bekerja

Sesuai [5] Definisi desa berdasarkan Undangundang Nomor 06 Tahun 2014 Tentang Desa sebagai berikut :

"Desa adalah desa dan desa adat atau yang disebut dengan nama lain, selanjutnya disebut Desa, adalah kesatuan masyarakat hukum yang memiliki batas wilayah yang berwenang untuk mengatur dan mengurus urusan pemerintahan, kepentingan masyarakat setempat berdasarkan prakarsa masyarakat, hak asal usul, dan / atau hak tradisonal yang diakui dan dihormati dalam sistem pemerintahan Negara Kesatuan Republik Indonesia"

Nampak jelas desa yang didefinisikan dan diungkap dalam undang-undang memiliki orientasi menjaga kepentingan masyarakat yang diprakarsai oleh masyarakat itu sendiri. Mengurus urusan pelayanan kepada masyarakat dan menciptakan kemandirian masyarakat merupakan bagian dari tugas pokok pemerintah. Desa dengan segala potensi yang dimiliki, akan berupaya menghadirkan kesejateraan ekonomi bagi masyarakat dengan mengoptimalkan pengelolaan potensi yang dimiliki. Meskipun kondisi dan potensi desa terkadang memiliki kesamaan dengan desa lainnya namun yang nampak nyata terjadi perbedaan pada dimensi masyarakatnya. Berikut klasifikasi desa dari perspektif perkembangan masyarakat Desa terdiri dari beberapa tipe yaitu:

1. Desa tradisional (Pradesa)
Karakteristik dari desa tradisional, ketergantunan masyarakat terhadap sumber daya alam masih sangat tinggi untuk memenuhi kebutuhan sehari-hari. Memiliki kepercayaan tehadap kekuatan mistis masih terpelihara dengan baik sebagai konsekuensi atas ketergantungan terhadap alam. Cendrung menolak perkembangan teknologi dan masih menggunakan peralatan tradisional hasil peninggalan nenek moyang.

2. Desa Swadaya

Masyarakatnya hidup secara mandiri dan tidak sepenuhnya lagi menggantungkan diri pada sumber daya alam. Interkasi sosial masyarakat berjalan dengan baik dengan ikatan emosional, meskipun intraksi dengan masyarakat diluar desa masih sangat terbatas

3. Desa Swakarya

Masyarakat yang dihidup di desa swadaya lebih terbuka terhadap masyarakat diluar desa sehingga memungkinkan masuknya informasi dan ilmu pengetahuan yang berdampak pada perkembangan desa dengan mengadopsi tata cara produksi untuk memenuhi kebutuhan hidup masyarakat desa setempat. Jika memiliki kelebihan produksi akan dijual atau dipertukarkan dengan barang lain yang berasal dari desa lain.

4. Desa Swasembada

Lebih maju lagi dibanding dengan desa swakarya, desa swasembada sudah mengenal pola produksi yang lebih modern dan memanfaatkan seluruh potensi ekonomi desa untuk meningkatkan ekonomi masyarakat pedesaan

Lahirnya Undang-undang No.06 Tahun 2014 tentang Desa menjadi perangkat hukum memajukan desa karena melalui undang undang ini pemerintah desa mendapatkan dana desa yang berasal dari Anggaran Pendapatan Dan Belanja Negara selain pendapatan yang berasal dari Bantuan Propinsi, bagi hasil pajak dan retribusi daerah dari kabupaten dan Alokasi Dana Desa dari kabupaten dan kota serta pendapatan asli desa.Sumber penerimaan yang diperoleh oleh pemerintah desa dapat menjadi stimulasi bagi desa menaikkan status dari desa tradisional (indikator ekonomi) menjadi desa Swadaya, dari sebelumnya desa Swadaya menjadi desa Swakarya, dari desa Swakarya menjadi desa Swasembada. Perubahan status ini sejalan dengan semangat dari undang-undang desa.

\section{Metodologi Penelitian}

Penelitian ini menggunakan pendekatan deskriptif kualitatif, yaitu suatu metode penelitian dengan memberikan penjelasan objektif tentang realitas objektif yang terjadi di suatu kondisi atau lingkungan. Konteks penelitian ini menggambarkan tentang pemanfaatan asset yang dimiliki oleh pemerintah desa sebagai upaya penciptaan lapangan 
kerja bagi masyarakat pedesaan. Teknik pengumulan data yang digunakan yakni obeservasi, wawancara mendalam, studi kepustakaan dan dokumentasi.

Metode penelitian deskriptif kualitatif digunakan untuk memecahkan suatu permasalahan dan menawarkan solusi atas pemasalahan tersebut. Penelitian ini menggambarkan masalah pengangguran yang ada di pedesaan dan memberikan solusi melalui pemanfaatan asset desa sebagai upaya penurunan tingkat pengangguran di pedesaan. Hal ini sejalan dengan apa yang telah disampaikan oleh Menurut Kirk dan Miller dalam Armaidy Armawi [6] penelitian kualitatif adalah sebagai " Tradisi tertentu dalam ilmu pengetahuan social yang secara fundamental bergantung pada pengamatan pada manusia dalam kawasan sendiri dan berhubungan dengan orang-orang tersebut dalam bahasa dan peristilahannya. Penelitian ini akan memberikan model pemanfaaatan asset desa yang dapat memciptakan lapangan kerja bagi masyarakat pedesaan sekaligus meningkat pendapatan asli desa.. Penelitian ini akan dilakukan pada dua desa. Pertama, Desa Mandalamekar, salah satu desa berkembang yang ada di kecamatan Cimenyan Propinsi Jawa Barat. Kedua, Desa Cikadut Kec. Cimenyan Propinsi Jawa Barat. Desa Cikadut merupakan salah satu desa maju yang terdapat di kecamatan Cimenyan yang ditandai dengan infrastruktur desa. Tahapan kegiatan yang dilakukan dalam penelitian ini tahap awal melakukan studi lapangan ke desa yang menjadi tempat penelitian. Wawancara beberapa perangkat desa yang memiliki fungsi pengelolaan aset desa. Selain melakukan wawancara, dalam penelitian ini juga akan melakukan analisa data invetaris asset tujuannya untuk memperoleh informasi tentang asset yang dimiliki oleh pemerintah desa tetapi tidak berfungsi secara optimal dalam rangka penyelenggaraan pemerintahan desa. Berdasarkan data yang tersedia selanjutnya dilakukan analisa untuk menghasilkan model pengelolaan asset yang dapat mendorong penciptaan lapangan kerja bagi masyarakat desa.

Pendekatan kualitatif memperoleh pemahaman tentang permasalahan yang dihadapi melalui pengumpulan data lapangan dimana informan berdomisili [7]. Informan berasal dari unsur perangkat desa yaitu Kelapa Urusan Umum memiliki tugas pokok pengelolaan atas aset desa. Kepala Urusan Keuangan bertugas mengelola keuangan dan Sekertaris Badan Usaha Milik Desa. Masing-masing informan berasal dari desa mandalamekar dan desa cikadut. Untuk mendapatkan informasi setiap informan diwawancara dengan menggunakan catatan yang berisi point-point yang akan ditanyakan. Wawancara menggunakan alat bantu recorder agar setiap informasi yang terakam. Selain metode wawancara, metode observasi terapkan untuk mengamati pola pengelolaan aset desa yang diterapkan masing-masing desa sekaligus mencari dokumen yang akan menguatkan hasil penelitian. Saat melakukan kunjungan lapangan beberapa spot aset desa diambil gambarnya sebagai materi visualisasi dalam laporan penelitian proses ini biasa disebut dengan metode dokumentasi. Untuk mengkonfirmasi kebenaran data yang diperoleh digunakan teknik triangilasi data dengan cara melakukan cek silang diantara data yang telah diperoleh dari setiap sumber data[8], hasilnya akan menjadi pijakan untuk menyusun model pemberdayaan berbasis aset desa.

\section{Pembahasan}

\section{Deskripsi Desa Mandala Mekar}

Desa Mandala mekar merupakan salah satu desa yang berada di wilayah administrasi kecamatan Cimenyan, Kabupaten Bandung. Secara geogerafis diapit oleh desa Cikadut dan Desa Ciburial, kedua desa tersebut berada pada kecamatan yang sama yaitu Kecamatan Cimenyan. Berdasarkan data pada bulan Oktober 2017, jumlah Penduduk Desa Mandalamekar sebanyak 7.542 orang dengan jumlah Kepala Keluarga (KK) sebanyak 2.088 KK. Jumlah usia produktif pada tahun 2016 sebanyak 2.428 Orang. Jumlah tersebut jika dilihat dari latar belakang pendidikan untuk kluster tamat SD / Sederajat sebesar 32\%, Tamat SMP/Sederajat $19 \%$, Tamat SMA / Sederajat $23 \%$, Tamat Akademi/Sederajat $8 \%$, dan Tamat Perguruan Tinggi / Sederajat $18 \%$. Berdasarkan persentase tersebut, proporsi terbesar angkatan kerja produktif dengan latar belakang pendidikan tamantan Sekolah Dasar (SD) sebesar 32\% disusul secara berurutan Sekolah Menengah Atas (SMA) dan Sekolah Menengah Pertama (SMP).

\section{Profile Aset Desa Mandalamekar}

Pada tabel profile aset bergerak desa menginformasikan sumber daya aset yang dimiliki oleh pemerintah desa Mandalamekar selama ini digunakan untuk penyelenggaraan pemerintahan dan pelayanan kepada masyarakat. Sumber pembiayaaan seluruh aset desa diperoleh dengan menggunakan anggaran yang berasal dari Anggaran Pendapatan dan Belanja Desa. Aset desa dikelola sesuai dengan ketentuan peraturan perundangundangan yang berlaku. Regulasi aset desa diatur dalam Peraturan Menteri Dalam Negeri No. 01 Tahun 2016 Tentang Pengelolaan Aset Desa. Berisi aturan formal yang mengatur teknis pengeloaan aset desa dan sekaligus menjadi acuan bagi perangkat pengelola aset melakukan menatausahakan dan mempertanggunjawabkan aset desa kepada kepala desa selaku pemegang kekuasaan atas aset desa. Melalui Direktorat Jenderal Bina Pemerintahan Desa, diterbitkan Pedoman umum Kodefikasi Aset Desa yang merupakan penjelasan lebih lanjut dari 
peraturan menteri dalam negeri tentang aset desa. Penyeragaman sistem kodefikasi aset desa merupakan langkah tertib adminstrasi agar keberadaan aset desa dapat terjaga dengan baik, terutama upaya pengamanan. Tidak sedikit aset desa tidak jelas keberadaannya karena disebabkan cara pengelolaan aset yang tidak tertib. Akibatnya, aset yang dimiliki oleh pemerintah desa justru pindah tangan kepada pihak-pihak tertentu yang mengklain kepemilikan atas aset tersebut. Tindakan demikian merugikan pemerintah desa dari sisi kekayaan dan akan menggangu proses pelayanan jika aset tersebut digunakan sebagai penunjang pelayanan kepada masyarakat.

Tabel 2

Profile Aset Tanah Desa

\begin{tabular}{|c|l|c|c|l|}
\hline No & Lokasi aset & Tahun beli & $\mathrm{m}^{2}$ & Fungsi \\
\hline 1 & $\begin{array}{l}\text { Kp. Tembung } \\
\text { Tuhur 04 / 11 }\end{array}$ & 1999 & 550 & $\begin{array}{l}\text { Lahan } \\
\text { Tidur }\end{array}$ \\
\hline 2 & Kp. Sinom & 1989 & 300 & $\begin{array}{l}\text { Kantor } \\
\text { Desa }\end{array}$ \\
\hline 3 & Kp. Sinom & 2007 & 140 & $\begin{array}{l}\text { Kantor } \\
\text { Desa }\end{array}$ \\
\hline 4 & Kp. Cibanten & 2007 & 1500 & $\begin{array}{l}\text { Sekola } \\
\text { h Dasar }\end{array}$ \\
\hline 5 & $\begin{array}{l}\text { Griya Mandala } \\
\text { Permai }\end{array}$ & 2005 & 220 & $\begin{array}{l}\text { GOR } \\
\text { Deesa }\end{array}$ \\
\hline
\end{tabular}

Sumber: Diolah Sesuai Buku Aset Tanah Desa

Pada awalnya aset desa masuk dalam perencanaan pengadaan karena dapat digunakan untuk nenunjang pelayanan kepada masyarakat. Namun dalam proses penggunaannya terkadang justru aset tidak dapat digunakan secara optimal sehingga keberadaan aset hanya menjadi beban bagi anggaran desa. Demikian adanya yang terjadi pada desa mandalamekar, tanah desa seluas $550 \mathrm{M} 2$ menjadi lahan tidur yang tidak produktif tetapi justru mengkonsumsi beban pemeliharaan setiap tahun yang harus anggarkan oleh pemerintah desa. Secara ekonomis, tanah kas desa yang tidak produktif akan merugikan desa, membutuhkan biaya pemeliharaan tapi tidak menghasilkan pendapatan ataupun tidak memberikan manfaat pelayanan kepada masyarakat. Berbeda dengan tanah kas desa seluas 1500 M2, diatas tanah tersebut terdapat bangunan sekolah yang berfungsi memberikan pelayanan pendidikan. Tentu ukuran kemanfaatannya bukan besaran pendapatan yang diperoleh tetapi tingkat pelayanan pendidikan yang dirasakan oleh masyarakat[9]. Keberadaan tanah kas desa yang tidak produktif membutuhkan solusi agar dapat merubah kondisi tanah menjadi produktif. Tentu hal demikian menjadi tantangan bagi perangkat desa terutama kepala desa agar dapat mengoptimalkan seluruh aset desa yang miliki agar memberikan manfaat bagi pemerintah desa dan masyarakatnya. Manfaat atas hasil optimalisasi aset desa dapat berupa pendapatan bagi desa atau lewat pembukaan lapangan kerja bagi masyarakat desa dengan menggunakan aset tanah yang tidak produktif. Tentu pembukaan kesempatan kerja bagi masyarakat desa lewat pemanfaatan tanah tidak produktif dengan cara bertani atau berkebun bukan satu-satunya cara optimalisasi.

Skema kerjasama Bangun Guna Serah (BGS) merupakan salah satu skema yang dapat digunakan oleh pemerintah desa mandalamekar untuk langkah optimal atas aset tidak produktif. BGS merupakan pola kerjasama dengan pihak lain, baik perseorangan ataupun korporasi dengan memberikan hak pakai atas tanah kas desa dalam jangka waktu tertentu untuk tujuan komersial. Bagi pemerintah desa, pemberian hak pakai kepada pihak lain akan memperoleh kompensasi sesuai dengan kesepakatan kerjasama. Terdapat unsur bangunan dalam kerjasama BGS, sampai masa kerjasama berakhir maka bangunan yang berdiri diatas tanah kas desa berpindah hak menjadi milik desa. Bangunan hasil peninggalan BGS dapat digunakan oleh pemerintah desa untuk kepentingan masyarakat. penting bagi pemerintah desa untuk memperjuangkan dalam dalam kausul kerjasama BGS keterlibatan masyarakat dalam kegiatan ekonomi, menekankan penggunaan tenaga kerja yang berasal dari masyarakat desa setempat sehingga kehadiran pihak korporasi melalui BGS memberikan dampak penurunan angka penganguran yang ada di desa mandalamekar yang jika melihat data statistiknya cukup besar. Selain klausul penggunaan tenaga kerja lokal, pemerintah desa juga dapat mendorong penggunaan material atau produk lokal yang berasal dari desa setempat untuk kegiatan operasional usaha pihak korporasi. Upaya seperti ini dapat mendorong kelompok masyarakat ekonomi di pedesaan seperti usaha rumahan (Home Industry) atau Usaha Kecil Menengah (UKM) untuk ikut tumbuh dan berkembang seiring dengan perkembangan usaha korporasi. Sinergisitas yang dimediasi melalui optimalisasi aset antara pemerintah desa dan korporasi akan dapat menjadi mesin penggerak roda ekonomi pedesaan.

\section{Tabel 3}

Rekapitulasi Aset Rusak Mandalamekar

\begin{tabular}{|c|l|c|c|}
\hline No & Jenis Aset Desa & $\begin{array}{c}\text { Tahun } \\
\text { Beli }\end{array}$ & $\begin{array}{c}\text { Status } \\
\text { Rusak }\end{array}$ \\
\hline 1 & Sofa \& Meja & 2013 & 1 Set \\
\hline 2 & Printer & 2012 & 2 Unit \\
\hline 3 & Mesin Ketik & 2006 & 1 Unit \\
\hline 4 & TV LED 32” & 2005 & 1 Unit \\
\hline 5 & Meja Kerja & 2011 & 2 Unit \\
\hline 6 & Papan Monografi & 2005 & 1 Unit \\
\hline 7 & Kompor Gas & 2015 & Unit \\
\hline
\end{tabular}

Sumber: Diolah Sesuai Buku Inventaris Aset Desa

Selain optimalisasi potensi aset yang dapat ditempuh pemerintah desa untuk mendorong aktivitas ekonomi masyarakat pedesaan, terdapat peluang lain yang dapat dilakukan untuk mendapatkan hasil yang sama, diluar jalur kerjasama Bangun Guna Serah. Pada tabel Rekapitulasi aset Rusak Desa di kolom Status, 
menunjukkan status aset dalam kondisi rusak. artinya aset desa tidak difungsikan lagi untuk menunjang penyelenggaraan pemerintah desa dan pelayanan kepada masyarakat. Disfungsi pada aset karena pertimbangan kondisi aset mengalami kerusakan parah, selanjutnya aset bersangkutan akan dimasukkan dalam gudang penyimpanan aset desa yang sudah tidak terpakai (rusak parah). Aset yang sudah rusak dan tidak terpakai lagi, sesuai dengan peraturan pengelolaan aset desa wajib di musnahkan salah satunyadengan cara dibakar. Proses pemusnahan disaksikan oleh beberapa perangkat desa dan dibuat berita acara pemusnakan dengan dilampiri bukti dokumentasi pemusnahan aset. Berita acara pemusnahan aset menjadi dasar bagi perangkat desa yang memiliki fungsi pengelola aset desa untuk melakukan penghapusan aset dari buku inventaris aset desa. Demikian tahapan yang diamanatkan dalam peraturan pengelolaan aset desa jika

Pemerintah desa akan melakukan tahapan pemusnahan. Secara regulasi pemusnahan aset desa yang sudah digudangkan dapat dikatakan sudah betul secara prosedural pengelolaan aset desa, namun jika melihat kondisi aset yang akan dimusnahkan masih nampak memiliki nilai ekonomis, meskipun tidak sebesar kalau masih berfungsi normal. Terasa berat melihat aset desa yang masih memiliki kondisi layak ekonomis dimusnahkan, suku jawa nyebutnya "hemanheman". Perlu langkah terobosan atas aset desa yang rusak dan tidak terpakai agar tidak harus

\section{Profile Aset Desa Cikadut}

Strategi pemanfaatan aset yang dimiliki oleh pemerintah desa Cikadut berdasarkan aset dalam bentuk tanah kas desa yang belum optimal penggunaannya, dan aset desa yang sudah diputuskan tidak dapat digunakan dalam penyelenggaraan pemerintah desa karena kondisi aset sudah rusak. Kedua kriteria aset tersebut pemanfaatannya akan dioptimalkan agar dapat memberikan manfaat lebih bagi pemerintah dan masyarakat desa. Untuk aset tanah kas desa terdapat sumber mata air yang selama ini dialirkan ke rumah warga yang berada di desa Cikadut, digunakan untuk memenuhi kebutuhan air rumah tangga. luas tanah sekitar $3.500 \mathrm{~m}^{2}$, tentu dengan ukuran tanah yang cukup luas, hanya memanfaatkan sumber mata air nampaknya optimalisasi pemanfaatan atas tanah belum maksimal, jika dibandingkan dengan potensi yang dimiliki oleh aset tanah tersebut. Pemanfaatan atas tanah kas desa selain memanfaatkan sebagai sumber mata air bagi warga desa, berpotensi untuk menciptakan objek wisata alam dan minat khusus. Potensi sumber mata air yang terletak diatas tanah kas desa akan menjadi daya tarik ketika dibangun sebuah embung yang dapat menampung debit air sebelum dialirkan ke rumah warga. Embung akan menjadi magnet untuk menarik para pengunjung dimusnahkan tetapi ada upaya alternatif yang dapat dilakukan oleh pemerintah desa untuk menyalurkan aset rusak, salah satunya dengan cara menghibahkan kepada Badan Usaha Milik Desa (BUMDES). Bagi BUMDES hibah aset desa yang diterima dapat membentuk usaha baru "Toko Barang Bekas"diharapkan usaha ini akan menghasilkan sumber pendapatan usaha baru bagi Unit usaha desa, berakhir pada peningkatan pendapatan bagi pemerintah desa[10]. Tentu langkah ini membutuhkan dukungan semua unsur dan pihak yang berkepentingan agar inisiatif tidak mendapat hambatan baik pada saat perumusan perencanaan maupun pada saat pelaksanaan kebijakan desa.

Tabel 4

Profile Inventaris Gedung

\begin{tabular}{|c|l|l|l|}
\hline No & Letak Gedung & Fungsi & M2 \\
\hline 1 & Kp Sinom RT 03/04 & Kantor Desa & 440 \\
\hline 2 & $\begin{array}{l}\text { Griya Mandala Permai } \\
\text { RW 13 }\end{array}$ & GOR Desa & 220 \\
\hline
\end{tabular}

Sumber: Diolah sesuai Buku Aset Gedung Desa

Inventaris gedung memiliki potensi pendapatan lainnya bagi pemerintah desa. Pemanfaatan gedung GOR desa dapat menghasilkan pendapatan bagi desa sehingga untuk mencapai optimalisasi pemanfaatan gedung sebaiknya pengelolaan diserahkan kepada badan usaha desa yang sejak dari awal didirikan untuk mengolah sumber daya desa secara professional dan berbasis pada bisnis desa.

datang berlibur dan bersantai menikmati alam terbuka di tepi embung sambil menikmati pemandangan kota bandung dan sekitarnya dari titik ketinggian. Untuk mewujudkannya tentu membutuhkan dukungan penuh dari pemerintah desa dan warga setempat. Sangat dibutuhkan kolaborasi yang harmonis antara warga desa yang akan menjadi pelaksana dan diberikan wewenang untuk mengelola destinasi wisata dibawah pengarahan dari pihak pemerintah desa. Seperti yang ada dibeberapa desa yang sedang mengelola destinasi wisata didesa pengeloaan berada pada Badan Usaha Milik Desa (BUMDES), upaya demikian juga dapat digunakan oleh desa cikadut mengelola potensi wisata disana yang ada disana. BUMDES yang sudah terbentuk dan beroperasi selama tiga tahun menjadi pihak pengelola destinasi wisata desa cikadut. Unit usaha desa sebagai pengelola sebaiknya melibatkan kelompok masyarakat seperti karang taruna dan memprioritaskan masyarakat desa cikadut yang belum memiliki pekerjaan untuk ikut berperan mengelolah wisata. keberadan objek wisata desa akan menjadi peluang bagi warga untuk mendapatkan pekerjaan dan penghasilan dapat memenuhi kebutuhan dasar rumah tangga. 


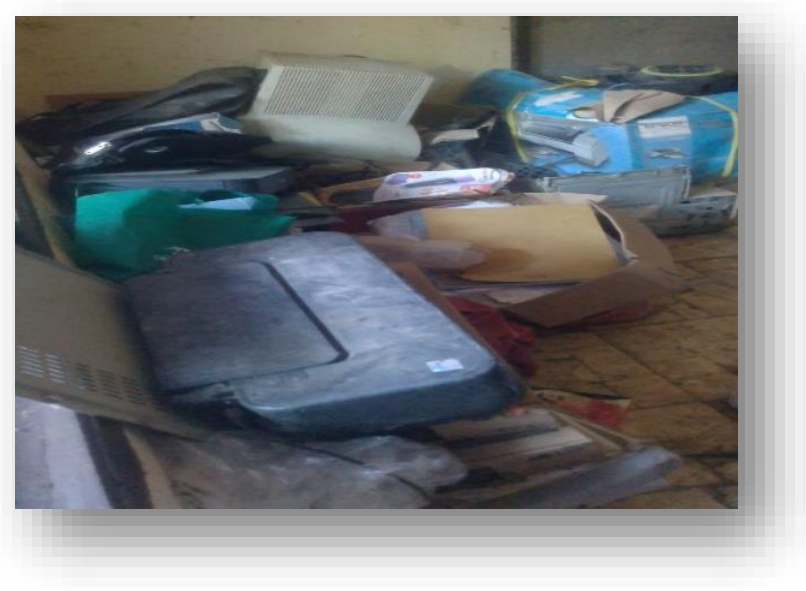

Tabel 5

Rekapitulasi Aset Tetap Desa Cikadut

\begin{tabular}{|c|l|c|c|c|}
\hline No & Letak Aset & $\begin{array}{c}\text { Tahun } \\
\text { beli }\end{array}$ & $\mathrm{m}^{2}$ & Fungsi \\
\hline 1 & Desa Cikadut & 2006 & 3500 & Sumber mata air \\
\hline 2 & Kantor desa & 2018 & 600 & $\begin{array}{l}\text { Gedung Kantor } \\
\text { desa Cikadut }\end{array}$ \\
\hline
\end{tabular}

Diolah Berdasarkan Buku Tanah Desa

Selain menawarkan destinasi wisata, pengelola berupaya untuk melibatkan kelompok masyarakat ekonomi yang ada di desa cikadut. Kelompok masyarakat pengrajin angklung dapat memasarkan hasil produksi angklung, termasuk kelompok usaha kuliner berada di sekitar desa cikadut. Semua potensi produk desa dapat dipasarkan disekitar lokasi wisata sebagai produk turunan dari destinasi wisata desa cikadut yang ditawarkan. Inovasi produk wisata yang berpotensi dilakukan dengan menampilkan pementasan terbuka, seni musik angklung sebagai alat musik utama, akan menjadi

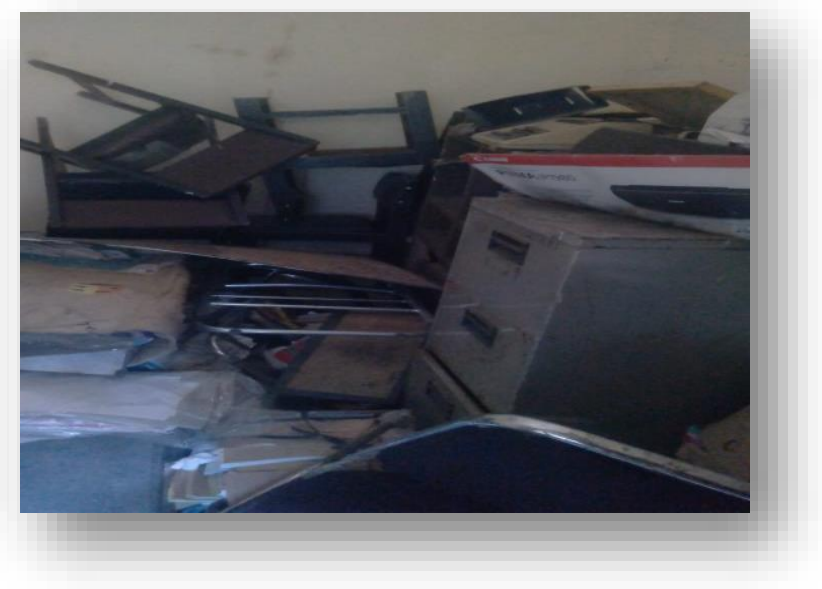

hiburan tambahan ketika berkunjung ke desa wisata cikadut.

Tabel 7

Rekapitulasi Aset Rusak Desa Cikadut

\begin{tabular}{|c|l|c|c|c|}
\hline No & $\begin{array}{c}\text { Jenis } \\
\text { Aset }\end{array}$ & $\begin{array}{c}\text { Tahun } \\
\text { Beli }\end{array}$ & Total & Status \\
\hline 1 & Printer & 2013 & 1 & Rusak \\
\hline 2 & Printer & 2014 & 1 & Rusak \\
\hline 3 & $\begin{array}{l}\text { Camera } \\
\text { Digital }\end{array}$ & 2015 & 1 & Rusak \\
\hline
\end{tabular}

Diolah sesuai Buku Inventaris Aset Desa

Sementara aset desa yang sudah tidak digunakan dikarenakan rusak, selanjutnya dapat diserahkan dengan cara hibah kepada BUMDES, dan pemanfaatannya akan diupayakan dalam bentuk membuka toko "Barang Bekas". Hasil penjualan barang bekas akan menjadi sumber pendapatan baru bagi badan usaha desa Cikadut

Gambar 3 Gudang Penyimpanan Aset Rusak

\section{DIAGRAM 4. PEMBERDAYAAN BERBASIS ASET DESA CIKADUT}

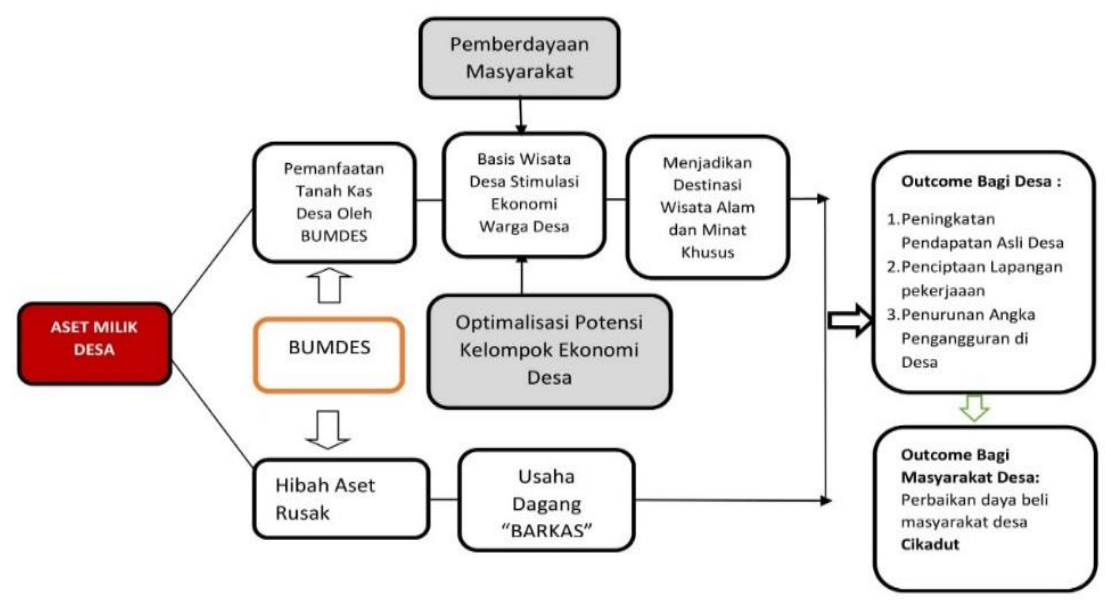


Nampak pada model alur pengelolaan aset tanah kas desa dalam bentuk pemanfaatan menjadi destinasi wisata yang diakselerasi dengan produk lokal desa cikadut akan mendorong penyerapan tenaga kerja bagi warga desa cikadut. Kesempatan kerja sektor wisata, bagi warga desa cikadut akan menurunkan jumlah angka pengangguran, pada saat sama meningkatkan daya beli masyarakat desa cikadut. Bagi pemerintah desa sendiri, kehadiran destinasi wisata akan meningkatkan pendapatan asli desa yang diperoleh dari bagi hasil pengelolaan wisata oleh BUMDES. Pada situasi ini badan usaha desa menjadi motor penggerak bagi ekonomi masyarakat dan peningkatan pendapatan bagi pemerintah desa[11]

\section{Kesimpulan}

1. Pemberdayaan masyarakat desa melalui pemanfaatan aset desa membutuhkan pemikiran inovatif dari semua pihak, khususnya pihak pemerintah desa selaku pemegang keuasaan atas pengelolaan aset desa. Tanah kas desa dan barang rusak yang dimiliki oleh pemerintah desa cikadut dan mandalamekar belum memberikan hasil optimal, baik kepada pemerintah maupun masyarakat desa. Sehingga keberadaan aset yang pemanfaatannya tidak optimal justru menjadi beban bagi anggaran belanja desa, alokasi belanja pemeliharaan aset. Bagi pemerintah desa, kemampuan memanfaatkan peluang ekonomis atas tanah kas desa yang belum optimal, membutuhkan kemampuan manajerial aset yang semestinya dimiliki oleh para pengelola aset desa.

2. Badan Usaha Milik Desa (BUMDES) merupakan unit usaha desa berperan mendorong peningkatan aktivitas ekonomi masyarakat pedesaan. Optimalisasi pemanfaatan tanah kas desa dapat sepenuhnya diserahkan kepada BUMDES agar hasil dari pemanfaatan ikut dirasakan oleh masyarakat pedesaan.

3. Masih terkait saran pada point 2. Sesuai dengan realitas yang ditemukan saat melakukan observasi dan wawancara kepada informan, beberapa pengurus BUMDES memiliki tingkat keaktifan masih rendah karena persoalan urusan rumah tangga masing-masing pengurus. Kondisi demikian menjadi kendala bagi pengembangan badan usaha desa. Saran kedepan, bagi pemerintah desa yang menetapkan pengurus agar mempertimbangkan permasalahan demikian, agar pengelolaan unit usaha desa tidak terbengkalai sehingga badan usaha desa dapat mewujudkan cita-citanya sebagai "Penggerak Roda Perekonomian Desa".

4. Salah satu unsur kelembagaan yang terdapat di desa tetapi kurang menjadi sorotan dan perhatian yaitu kelompok karang taruna. Diketahui bersama bahwa karang taruna merupakan lembaga formal yang berisi remaja potensial dengan tingkat kreativitas tinggi, sesuai dengan jiwanya berani mencoba hal baru. Sebaiknya pemerintah desa dapat memberdayakan kelompok karang taruna terutama dalam dibidang sosio-ekonomi desa.

\section{Keterbatasan :}

Beberapa keterbatasan yang terdapat dalam penelitian sebagai berikut :

1. Penelitian ini berfokus pada aset desa yang selama ini pemanfaatannya masih belum optimal dan aset kondisi rusak berat. Sementara masih terdapat beberapa aset yang dapat dimanfaatkan tetapi belum tereksplorasi secara mendalam dalam penelitian ini.

2. Ketersediaan data tentang latar belakang pekerjaan penduduk desa Mandalamekar yang jumlahnya masih belum dapat dipastikan oleh pihak pemerintah desa, meskipun telah terpublikasi dalam laman web pemerintah desa mandalamekar namun jumlahnya belum pasti.

\section{Daftar Pustaka}

Indonesia, K.D.N.R., Peraturan Menteri Dalam Negeri Republik Indonesia Nomor 113 Tahun 2014 Tentang Pengelolaan Keuangan Desa, in Nomor 113 Tahun 2014, K.D.N.R. Indonesia, Editor. 2014: Indonesia.

Indonesia, K.D.N.R., Peraturan Menteri Dalam Negeri Republik Indonesia Nomor 01 Tahun 2016, in 01 Tahun 2016, K.D.N.R. Indonesia, Editor. 2016, www.keuangandesa.com: Indonesia.

Pratama, C., Faktor-Faktor Yang Mempengaruhi Keberhasilan Pemberdayaan Perempuan Desa Joho Di Lereng Gunung Wilis. Kebijakan Dan Manajemen Publik, 2013. 1(01).

Pemerintah, K.S.A., Peraturan Pemerintah No. 71 Tahun 2010 Tentang Standar Akuntansi Pemerintah, P.R. Indonesia, Editor. 2010: Indonesai.

Indonesai, P.R., Undang-Undang Republik Indonesia Nomor 6 Tahun 2014 Tentang Desa, In Nomor 6 Tahun 2014, P.R. Indonesia, Editor. 2014, Lembaga Sekertariat Negara: Indonesia. p. 38.

Armaidy, A., Pemberdayaan Masyarakat Dalam Pengembangan Desa Wisata dan Implikasinya Terhadap Ketahanan Ekonomi Keluarga Studi Desa Wisata Brayut Pandowoharjo SlemanYogyakarta. Buku Hibah Penelitian Dosen SEkolah Pascasarjana - UGM. 2015, Yogyakarta: Penerbit Sekolah Pascasarjana Universitas Gadjah Mada. 
Creswell, J.W., Penelitian Kualitatif \& Desain Riset. Edisi 3 ed. 2015, Yogyakarta: Pustaka Pelajar. 634.

Mungin, B., Analisis Data Penelitian Kualitatif. Pemahaman Filosofis dan Metodologis ke Arah Penguasaan Model Aplikasi. 2015, Jakarta: Rajagrafindo Persada. 274.

Indra, B., Akuntansi Untuk Kecamatan dan Desa. 2011, Jakarta: Erlangga.

Rizka Hayyuna, R.N.P., Lely Indah Mindarti, Strategi Manajemen Aset Bumdes Dalam
Rangka Meningkatkan Pendapatan Desa. Jurnal Administrasi Publik, 2013. 4(2013).

Amanda, H.W., Strategi Pembangunan Desa Dalam Meningkatkan Pendapatan Asli Desa Melalui Badan Usaha Milik Desa (Bumdes). Jurnal Administrasi Negara 3(2015). 